\title{
Prevalensi Gejala Sindroma Terowongan Karpal Pada Ibu Hamil di Puskesmas Pancoran Mas Depok
}

\author{
Lusti Amelia Bahar ${ }^{1}$, Werda Indriarti ${ }^{2,3}$ \\ ${ }^{1}$ Program Pendidikan Dokter, Fakultas Kedokteran Universitas YARSI, Jakarta \\ ${ }^{2}$ Bagian Neurologi Fakultas Kedokteran Universitas YARSI, Jakarta \\ ${ }^{3}$ Bagian Neurologi Fakultas Kedokteran Universitas YARSI, Jakarta \\ Koresponden Email: werda.indriati@yarsi.ac.id;
}

\begin{abstract}
Abstrak
Sindroma Terowongan Karpal (STK) merupakan suatu kondisi dimana timbul rasa sakit yang progresif pada tangan dan lengan akibat tertekannya saraf medianus di pergelangan tangan. Saraf medianus merupakan salah satu saraf di tangan yang berjalan melewati suatu terowongan yang terletak di daerah pergelangan tangan. Gejala khas dari STK adalah mati rasa dan kesemutan di ibu jari, telunjuk, tengah, dan setengah radial dari jari manis. Prevalensi STK relatif tinggi pada wanita hamil karena adanya peningkatan berat badan yang signifikan dan perubahan hormon. Tujuan penelitian ini adalah mengetahui prevalensi gejala STK pada ibu hamil di Puskesma Pancoran Mas Depok. Jenis penelitian ini adalah deskriptif cross sectional dengan teknik survei menggunakan kuesioner. Populasi dan sampel penelitian adalah ibu hamil yang melakukan antenatal care (ANC) di Puskesmas Pancoran Mas Depok periode Maret-September pada tahun 2017, memenuhi kriteria inklusi dan ekslusi. Pemilihan sampel dengan simple random sampling. Analisis data menggunakan rumus prevalensi. Hasil penelitian menunjukkan prevalensi Sindroma Terowongan Karpal di Puskesmas Pancoran Mas Depok pada periode Maret - September 2017 adalah 32\%, gambaran faktor risiko terbanyak adalah wanita hamil multigravida, berat badan $>61 \mathrm{~kg}$, dan usia kehamilan trimester III.
\end{abstract}

Kata Kunci: prevalensi wanita hamil, sindrom terowongan karpal

\section{Abstract}

The Carpal Tunnel Syndrome is a condition that is progressive pain in the hands and arms due to the pressure of the median nerve on the wrist. The median nerve is one of the nerves in the hand that runs through a tunnel located in the wrist. A typical symptom is numbness and tingling in the thumb, forefinger, middle, and half radial of the ring finger. The prevalence of CTS is relatively high in pregnant women due to significant weight gain and hormonal changes. The purpose of this study was to determine the prevalence of CTS in pregnant women at Pancoran Mas Depok Public Health Center. This research design is a cross sectional of descriptive survey technique using a questionnaire and random sampling. Respondents were pregnant women who did antenatal care (ANC) at Pancoran 
Mas Depok Public Health Center in March-September 2017, fulfilling the inclusion and exclusion criteria. Data analysis used prevalence formula. The results showed The prevalence of CTS in Pancoran Mas Depok Public Health Center in March - September 2017 was 32\%, the most risk factors were multigravida pregnant women, body weight> $61 \mathrm{~kg}$, and third trimester gestational age.

Keywords: prevalence pregnant women carpal Tunnel syndrome

\section{Pendahuluan}

Sindroma Terowongan Karpal merupakan suatu kondisi dimana timbul rasa sakit yang progresif pada tangan dan lengan akibat tertekanya saraf di pergelangan tangan (saraf medianus). Saraf medianus merupakan salah satu saraf di tangan yang berjalan melewati suatu terowongan yang terletak di daerah pergelangan tangan (Aswoth, 2016).

Gejala khas dari Sindroma Terowongan Karpal adalah mati rasa dan kesemutan di ibu jari, telunjuk, tengah, dan setengah radial dari jari manis. Manifestasi umum lainnya termasuk nyeri seperti dibakar, nyeri pergelangan dan juga kehilangan kekuatan untuk menggenggam dan ketangkasan. Gejala-gejala yang lebih buruk pada malam hari dan dapat diperburuk oleh aktivitas berat dan posisi pergelangan tangan yang ekstrim. Pada kehamilan, kemung-kinan disebabkan oleh perubahan hormonal dan edema. Diabetes gestational juga dapat menimbulkan Sindroma Terowongan Karpal karena perlambatan umum konduksi saraf (Padua et al., 2001). Prevalensi gejala Sindroma Terowongan Karpal relatif tinggi pada wanita hamil. Prevalensi dan keparahan peningkatan Sindroma Terowongan Karpal dan kasus asimtomatik menurun sejalan dengan usia kehamilan. Pemeriksaan klinis dan pemeriksaan riwayat klinis tidak dapat mendiagnosa semua kasus, dan sensitivitas serta spesifitasnya sangat rendah dibanding uji elektrodiagnosis
(Jospt, 2016; Jurjevic, 2017).

Sindroma Terowongan Karpal umumnya terjadi secara kronis di mana terjadi penebalan fleksor retinakulum yang menyebab-kan tekanan terhadap nervus medianus. Tekanan yang berulang-ulang dan lama akan mengakibatkan peninggian tekanan intrafaskuler. Akibatnya aliran darah vena intrafaskuler melambat (Cunningham et al., 1988).

Tujuan dari penelitian ini adalah untuk mengetahui prevalensi gejala Sindroma Terowongan Karpal pada ibu hamil di Puskesmas Pancoran Mas Depok.

\section{Bahan dan Metoda Penelitian}

Jenis penelitian ini adalah deskriptif cross sectional. Populasi dan sampel adalah ibu hamil yang melakukan pemeriksaan antenatal care (ANC) di Puskesma Pancoran Mas yang memenuhi Kriteria inklusi yaitu ibu hamil dengan umur kehamilan 8-40 minggu, usia 20-50 tahun, bersedia mengikuti penelitian, memenuhi kriteria ekslusi yaitu Riwayat gejala Sindroma.

Terowongan Karpal sebelum kehamilan, riwayat trauma pergelangan tangan, riwayat Diabetes mellitus. Sampel dipilih dengan menggunakan simple random sampling dan berdasarkan rumus prevalensi didapatkan jumlah sample 97 ibu hamil. Pengumpulan data dilakukan dengan pengisian kuisoner. analisis 
data pada peneliti-an ini adalah deskriptif

\section{Hasil Penelitian}

Pada tabel 4.1 dapat dilihat bahwa distribusi frekuensi berdasarkan kehamilan anak keberapa analisis dapat disimpulkan Gejala Sindrom Terowongan Karpal terdapat pada kehamilan anak ke 2 (21,6\%) lebih banyak dibandingkan yang lain. Sedangkan untuk yang tidak terjadi Gejala Sindrom Terowongan Karpal terdapat pada kehamilan anak ke 1 $(13,4 \%)$ lebih banyak dibandingkan dengan yang lainnya.

Pada tabel 4.2 dapat dilihat distribusi frekuensi berdasarkan berat badan dapat disimpulkan 19 responden dengan berat badan $51-60(19,5 \%)$ dan >71 (19,5\%) lebih banyak diantara yang lain sedangkan untuk yang tidak terjadi Gejala Sindrom Terowongan Karpal terdapat pada responden yang memiliki berat badan $>71$ sebanyak 12 responden(12,4\%).

Pada tabel 4.3 dapat dilihat bahwa distribusi frekuensi berdasarkan berat badan menggunakan rumus prevalensi.

dapat disimpulkan 39 (40,2\%) responden usia 21 - 30 lebih banyak di antara yang lain. Sedangkan untuk yang tidak terjadi Gejala Sindrom Terowongan Karpal terdapat 21 (21,7\%) responden usia 21-30.

Pada tabel 4.4 dapat dilihat bahwa distribusi frekuensi berdasarkan berat badan dapat disimpulkan usia kehamilan yang mengalami gejala sindroma terowongan karpal trimester III sebanyak 48 (49,5\%) responden lebih banyak dari yang lain. Sedangkan untuk yang tidak mengalami Gejala Sindrom Terowongan Karpal pada usia kehamilan trimester III sebanyak $27(27,8 \%)$ responden.

Pada tabel 4.5 dapat dilihat bahwa total responden adalah 80, karena diantara 64 responden ada yang memilih 2 area tangan. Berdasarkan hasil analisis tersebut disimpulkan bahwa keluhan terbanyak pada area pergelangan tangan sebanyak 47 (58,75\%) responden.

Tabel 4.1. Distribusi Frekuensi Responden Penelitian Berdasarkan Kehamilan Anak Keberapa

\begin{tabular}{cccccccc}
\hline \multicolumn{2}{c}{ Gejala Sindroman Terowongan Karpal } \\
\hline \multirow{2}{*}{ Kehamilan Anak Ke } & \multicolumn{2}{c}{ Ya } & \multicolumn{3}{c}{ Tidak } & \multicolumn{3}{c}{ Total } \\
\cline { 2 - 8 } & $\mathrm{n}$ & $\%$ & $\mathrm{n}$ & $\%$ & $\mathrm{n}$ & $\%$ \\
\hline 1 & 19 & 19,6 & 13 & 13,4 & 32 & 33 \\
2 & 21 & 21,6 & 9 & 9,3 & 30 & 30,9 \\
3 & 16 & 16,5 & 7 & 7,2 & 23 & 23,7 \\
4 & 6 & 6,2 & 2 & 2,1 & 8 & 8,3 \\
5 & 1 & 1 & 2 & 2,1 & 3 & 3,1 \\
6 & 1 & 1 & - & & 1 & 1 & \\
\hline Total & 64 & 65,9 & 33 & 34,1 & 97 & 100 & \\
\hline
\end{tabular}


Tabel 4. 2 Distribusi Frekuensi Responden Penelitian Berdasarkan Berat Badan

\begin{tabular}{|c|c|c|c|c|c|c|c|c|}
\hline \multicolumn{9}{|c|}{ Gejala Sindroman Terowongan Karpal } \\
\hline \multirow{2}{*}{ Berat Badan (kg) } & & & & & \multicolumn{2}{|c|}{ Total } & \multirow[b]{2}{*}{$\%$} & \\
\hline & & $n$ & $\%$ & 7 & $\%$ & $n$ & & \\
\hline $1-50$ & & 10 & 10,3 & 10 & 10,3 & & 20 & 20,6 \\
\hline $51-60$ & & 16 & 16,4 & 3 & 3,1 & & 19 & 19,5 \\
\hline $61-70$ & & 19 & 19,5 & 8 & 8,5 & & 27 & 28 \\
\hline$>71$ & 19 & 19,5 & 12 & 12,4 & 31 & 31,9 & & \\
\hline Total & 64 & 65,7 & 33 & 34,3 & 97 & 100 & & \\
\hline
\end{tabular}

Tabel 4.3 Distribusi Frekuensi Responden Penelitian Berdasarkan Usia

\begin{tabular}{|c|c|c|c|c|c|c|}
\hline \multicolumn{7}{|c|}{ Gejala Sindroman Terowongan Karpal } \\
\hline \multirow[t]{2}{*}{ Usia } & \multicolumn{2}{|c|}{$\mathrm{Ya}$} & \multicolumn{2}{|c|}{ Tidak } & \multicolumn{2}{|c|}{ Total } \\
\hline & $\mathrm{n}$ & $\%$ & $\mathrm{n}$ & $\%$ & $\mathrm{n}$ & $\%$ \\
\hline $21-30$ & 39 & 40,2 & 21 & 21,7 & 60 & 61,9 \\
\hline $31-40$ & 23 & 23,7 & 9 & 9,3 & 32 & 33 \\
\hline $41-50$ & 2 & 2,1 & 3 & 3 & 5 & 5,1 \\
\hline Total & 64 & 66 & 33 & 34 & 97 & 100 \\
\hline
\end{tabular}

Tabel 4.4 Distribusi Frekuensi Penelitian Berdasarkan Usia Kehamilan

\begin{tabular}{ccccccc}
\hline \multicolumn{7}{c}{ Gejala Sindroman Terowongan Karpal } \\
\hline \multirow{2}{*}{ Usia Kehamilan } & \multicolumn{2}{c}{ Ya } & Tidak & \multicolumn{2}{c}{ Total } \\
\cline { 2 - 8 } & $\mathrm{n}$ & $\%$ & $\mathrm{n}$ & $\%$ & $\mathrm{n}$ & $\%$ \\
\hline Trimester I & 2 & 2,1 & 2 & 2,1 & 4 & 4,2 \\
Trimester II & 14 & 14,4 & 4 & 4,1 & 18 & 18,5 \\
Trimester III & 48 & 49,5 & 27 & 27,8 & 75 & 77,3 \\
\hline Totalal & 64 & 66 & 33 & 34 & 97 & 100 \\
\hline
\end{tabular}

Tabel 4.5 Distribusi Frekuensi Penelitian Berdasarkan Area Tangan yang Dikeluhkan

\begin{tabular}{ccc}
\hline \multicolumn{2}{c}{ Gejala Sindroman Terowongan Karpal } & \\
\hline Area tangan & $\mathrm{n}$ & $\%$ \\
\hline Pergelangan tangan & 47 & 58,75 \\
lbu jari & 13 & 16,2 \\
Tengah & 18 & 2 \\
Telunjuk & 2 & 2 \\
\hline
\end{tabular}




\section{Diskusi}

Hasil penelitian menunjukan bahwa prevalensi gejala Sindroma Terowongan Karpal pada wanita hamil di Puskesmas Pancoran Mas Depok sebanyak 32\%.

Dalam penelitian ini didapatkan responden yang mengalami gejala Sindroma Terowongan Karpal terbanyak pada usia kehamilan trimester III sebanyak 48 (49,5\%) responden, hal ini didukung oleh Meems (2015), yang menyatakan bahwa trimester III memiliki presentase yang sangat tinggi di-bandingkan trimester yang lainnya karena telah terjadi adanya peningkatan cairan pada wanita hamil khususnya pada trimester III, adanya edema lokal di terowongan karpal karena ada-nya perubahan hormon yang dapat mengakibat-kan Gejala Sindroma Terowongan Karpal.

Dalam penelitian ini didapatkan responden yang kita ketahui wanita hamil pasti memiliki menambahan berat badan yang sangat tinggi. Menurut Khoswari (2012) terjadinya peningkatan berat badan pada ibu hamil dapat menyebabkan peningkatan cairan pada terowongan karpal.

Dalam penelitian ini didapatkan sebagian besar responden ibu hamil yang mengalami gejala Sindroma Terowongan Karpal pada rentang usia

\section{Daftar Pustaka}

Asworth N. 2016. Carpal Tunnel Syndrome: Background, Pathophysiology, Epidemiology. [online] Available at: http://emedicine.medscape.com/artil e/327330-overview\#a5 [Accessed 12 Dec. 2016].

Cunningham ML, Walsh WE, Johnson EW. 1988. Determining neurapraxia in carpal tunnel syndrome. Am J Phys Med
21-30 tahun (40,2\%). Hal ini di dukung oleh Yazdanpanah (2012), yang menyatakan bahwa ibu hamil yang mengalami gejala Sindroma Terowongan Karpal terbanyak pada usia 25-50 tahun. Perubahan hormonal pada perempuan dapat menempatkan perempuan pada risiko lebih besar untuk mendapatkan gejala Sindroma Terowongan Karpal karena struktur pergelangan tangan yang membesar dan dapat menekan saraf di pergelangan tangan. Penelitian ini sesuai dengan per-nyataan dan Yazdanpanah (2012) bahwa yang sering mengalami gejala sindroma ini karena adanya perubahan hormon dan rata-rata umur ibu hamil pada usia 21-30 tahun.

Hasil penelitian juga didapatkan responden yang mengalami gejala Sindroma Terowongan Karpal terbanyak adalah pada wanita hamil multigravida 45 (46,3\%) responden.

\section{Simpulan}

Frekuensi Sindroma Terowongan Karpal di Puskesmas Pancoran Mas Depok pada periode Maret-September 2017 adalah 32\%. Faktor risiko terbanyak dari sindroma ini adalah wanita hamil multigravida dengan berat badan $>61 \mathrm{~kg}$, dan usia kehamilan trimester III.

Rehabil. 1988;67(3):117-119.

Jurjević A. 2017. Early onset of carpal tunnel syndrome during pregnancy: case report. - PubMed - NCBI. [online] Ncbi.nlm.nih.gov. Available at: https://www.ncbi.nlm. nih.gov/pubme d/20635589 [Accessed 12 Feb. 2017].

Jospt O. 2016. Clinical and Electrodiagnostic Testing of Carpal Tunnel Syndrome: A Narrative Review: Journal of Orthopaedic 
\& Sports Physical Therapy: Vol 34, No 10. [online]

Available at:http://www.jospt.org/doi/abs/10.2519/j ospt.2004.34.10.565?code=jospt site [Accessed 12 Dec. 2016].

Khosrawi S. and Maghrouri R. 2017. The prevalence and severity of carpal tunnel syndrome during pregnancy. Adv Biomed Res. 2012; 1: 43.

Meems M, Truijens S, Spek V, Visser LH, Pop VJ. 2015. Prevalence, course and determinants of carpal tunnel syndrome symptoms during pregnancy: a prospective study. BJOG.
Jul;122(8):1112-8. doi: 10.1111/14710528.13360 .

Padua L, Aprile I, Caliandro, P. 2001. Symptoms and neurophysiological picture of carpal tunnel syndrome in pregnancy. Clinical Neurophysiology, 112(10), pp.1946-1951.

Yazdanpanah P, Aramesh S, Mousavizadeh A, Ghaffari P, Khosravi Z, Khademi A. 2012. Prevalence and severity of carpal tunnel syndrome in women. Iran J Public Health. 41(2):105-10. Epub 2012 Feb 29. 